Paper title

\title{
Indigenous Bamboo and Resource Management in Kenya's Aberdare Forests and Rural Communities
}

\author{
Chika Sasahara ${ }^{1}$, Shozo Shibata ${ }^{2}$ \\ 1 Kyoto University Graduate School of Global Environmental Studies \\ 2 Kyoto University Graduate School of Global Environmental Studies, Graduate School of Agriculture \\ (double appointment) \\ * Corresponding author: sasahara.chika.27s@st.kyoto-u.ac.jp; tel. +81-(0)75-753-6084
}

\begin{abstract}
The Kenya Forestry Service permits rental of low-density national forest areas for use as common farmland, but public access to such areas is restricted to prevent deforestation against a background of rising demand for fuel wood. This study was conducted to clarify characteristics relating to the production of indigenous bamboo (a useful wood resource) by the approximately $23 \%$ of locals who work on common farmland in central Kenya's Kamae forest management area, with estimation to determine above-ground biomass. The results showed that bamboo still represents $60 \%$ of such biomass, indicating sustainability in the industry.
\end{abstract}

Keywords: bamboo, indigenous species, Kenya, AGB

\section{Introduction}

Around $80 \%$ of people in the developing nation of Kenya are dependent on the country's wood resources. In 2011, estimated national demand for fuel wood was approximately 37,000,000 $\mathrm{m}^{3}$ against a sustainable supply of only $30,000,000 \mathrm{~m}^{3}$ [1]. In relation to this shortfall, the Kenyan Forestry Service has reported illegal logging and collection of wood resources from national forests [1].

Wood resource production is accordingly promoted nationwide [2], but access to forest management areas is restricted in the interests of conservation. Resident groups can apply to use and manage common farmland [1], and around 6,355 people (1,370 households; $23 \%$ of the local population as of 2018) in the Kamae forest management area of Kiambu County use such land for drawing water, washing clothes, beekeeping and pond-based fish farming to create income [1]. The area's ethnic Kikuyu population traditionally uses indigenous vegetation to make herbal medicine and other items. Alpina bamboo grows naturally in Kamae highland areas at altitudes exceeding 2,000 m, and supports local livelihoods based on the ease of related processing [4]. However, research on indigenous bamboo in Kenya has been scarce.

This study focused on estimating the above-ground biomass (AGB) of indigenous bamboo in the Kamae forest management area of central Kenya to clarify related local application and useful vegetation resources.

\section{Target species and study area}

\section{2-1. Target species}

The indigenous Arundinaria alpina species was examined as one of 16 bamboo species found in Kenya [3]. The variety is known as Mwanzi in the country's Swahili language, and as Murangi in the local Kikuyu tribal dialect [1].

Stalk diameters vary from around 3 to $10 \mathrm{~cm}$, with culm heights up to about $20 \mathrm{~m}$. Rhizome types are Mixpodial type[1]. On the Aberdare range, the plant has a life cycle of more than 40 years. It flowers in patches of $0.5-5$ ha, extending over several hundred hectares of forest at a time [5], [6]. 


\section{2-2. Study area and environment}

The study focused on Kamae Forest Station in the southern part of Aberdare National Park in the Kamae district of Kiambu County (forest management area: 3,024 ha from $0^{\circ} 53^{\prime} 2^{\prime \prime} \mathrm{S} 36^{\circ} 38^{\prime} 5^{\prime \prime}$ to $0^{\circ} 45^{\prime} 50^{\prime \prime}$ $\mathrm{S} 36^{\circ} 40^{\prime} 8^{\prime \prime}$ (Fig. 1). The area has an altitude of $2,500-3,000 \mathrm{~m}$, an average annual temperature of $18^{\circ} \mathrm{C}$ and an average annual precipitation of $989 \mathrm{~mm}$ [1]. Fertile forest soil covers volcanic rocks formed during the formation of the Great Rift Valley there, creating an environment suitable for forest development and the production of potatoes as a local staple food. The climate generally has a dry season, a heavy rainy season in December and a light rainy season from late April to early May. Native vegetation includes seven types of broad-leaved trees (Podocarpus latifolias, Ocotea usambarensis, Ficus natalensis, Prunus africana, Juniperus procera, Dombeya goetzensii, Hagenia abyssinica), with A. alpina dominant as the bamboo type [1].

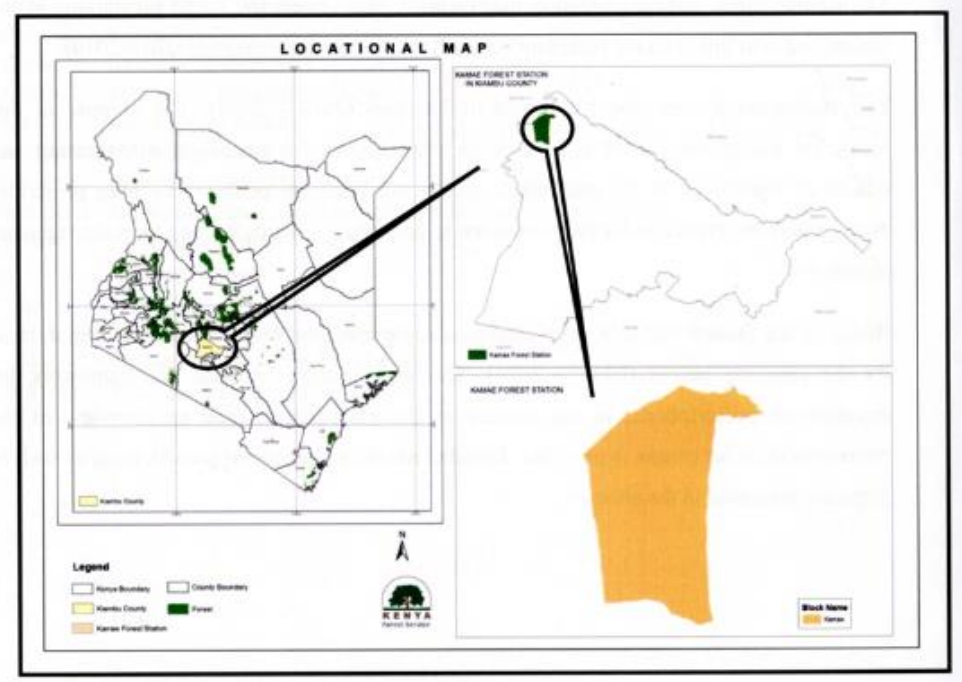

Figure 1. Kamae Forest Station study area

\section{2-3. Social background}

Kenyatta. J (1962) [7] reported that this area was connected to Aberdare National Park forest before the $18^{\text {th }}$ century. It is the main habitat of the Kikuyu tribal people, and has also served as a residence for local pygmies. British colonization from 1910 onward led to the foundation of the White Highlands in central Kenya, and the habitats of Kikuyu and other indigenous peoples were colonized for development of large-scale tea fields and pineapple plantations. Natives were forced to relocate to black settlements in eastern Nairobi or become plantation slaves. In 1929, Britain formed the Forest Department in East Africa, and the Kamae Forest Management Zone was established on December 21, 1943 [1]. The area became a refuge for Mau Mau soldiers fighting colonization in the 1950s with attacks on white farms and pro-Anglophile Kenyan groups in the area [8] prior to Kenya's declaration of independence in 1963. In 2007, the pre-independence Forestry Department was re-established as an independent administrative agency called the Kenya Forestry Service, and a common farmland system was formed. In 2014, the international environmental NGO Green Belt Movement proposed the management of 1,160 ha in the Kamae Forest Management Zone for carbon fixation [1]. The area of common farmland in Kamae Forest Station was 1,038.03 ha, representing 34.31\% of the total forest management area. As of 2017, many shared agricultural and forestry areas where cash crops were cultivated for income were observed in the area (Fig. 2). Here, non-common farmland regions in Kamae Forest Station are referred to as forest management areas. 


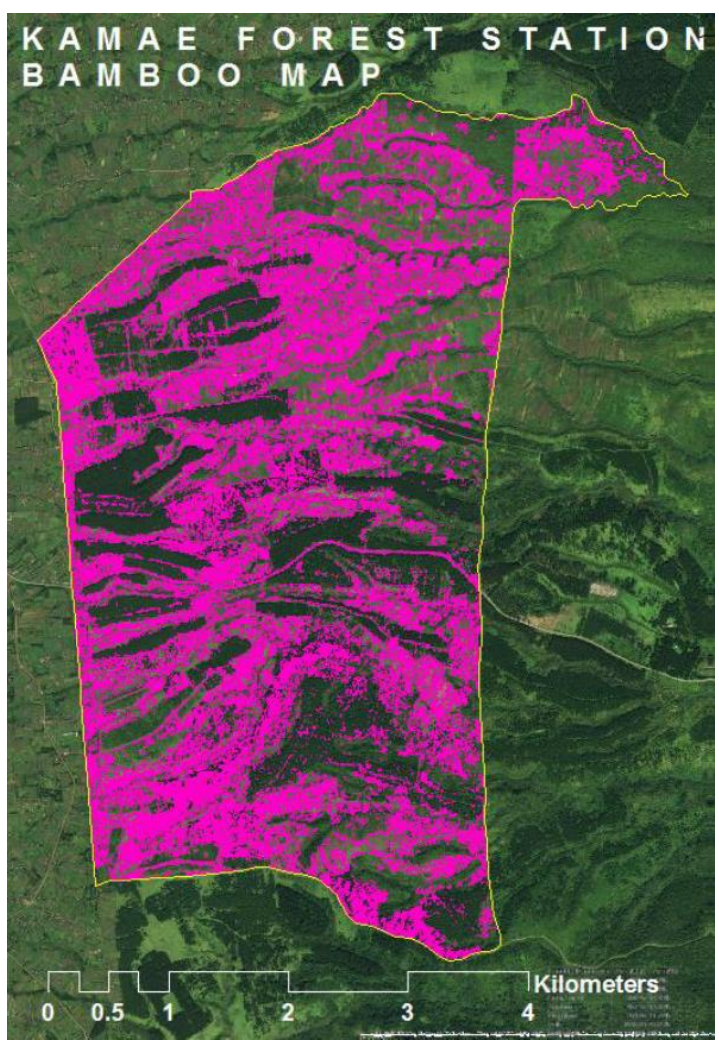

Figure 2. Common farmland area in Kamae Forest Station

\section{Methodology}

Efforts were made to clarify the characteristics of bamboo forests based on the results of related field surveying [9] and above-ground biomass (AGB) sampling work. To estimate indigenous forest-area bamboo distribution, GPS (Garmin GPSMAP 64) was used with a Kenya Forestry Service vehicle to record bamboo forest locations, and Arc-GIS was applied to determine the AGB of bamboo forest land at the Kamae site. Seven $10 \times 10 \mathrm{~m}$ plots were randomly selected in the area, with two set in bamboo forest on common farmland.

In each survey, bamboo diameter at breast height ( $\mathrm{DBH}$; determined with a tape measure at internode centers above the ground) and coordinate positions were recorded for each plot. The south side of square plots was set as the $\mathrm{X}$ axis and the west side as the $\mathrm{Y}$ axis, and the horizontal distance from each axis was measured.

With approval from the Kenya Forestry Service, details of 50 samples with different DBHs from the plots were recorded. The total lengths and sizes of culms, branches and leaves every meter from the ground were determined, and raw weight was established using a digital suspension instrument (TRUSCO TDTB-25) [10]. Inner DBH was also measured from cut samples.

Individual culms, branches and leaves were weighed at Jomo Kenyatta University of Agriculture and Technology after 72 hours in a dryer (Eyela Windy Oven WFO-1000ND) at $72^{\circ} \mathrm{C}$.

\section{Results}

\section{4-1. DBH distribution and density in forest management areas and on common farmland}

The bamboo area in Kamae Forest Station covered 467.37 ha (Fig. 3), with standing bamboo densities of 21,500/ha in Plot 1, 21,400/ha in Plot 2, 20,900/ha in Plot 3, 18,600/ha in Plot 4 and 17,500/ha in Plot 5 (average: 19,980/ha (Table 1)). M-M* regression analysis [12] was performed on culm distribution, and a related linear equation was developed (Table 2). The average $\alpha$ value for the five plots was 1.0364 and the $\beta$ value was 2.5196 , which is average for bamboo forest management areas 
and indicates concentrated culm distribution. The average DBH for the plots was $3.12 \mathrm{~cm}$, the median was $3.2 \mathrm{~cm}$, and the standard deviation was 0.88, with a range from 0.6 to $6.0 \mathrm{~cm}$ (Fig. 4).

On common farmland the figures were 11,300/ha in Plot 6 and 19,100/ha in Plot 7, representing an average of 15,200/ha (Table 3). M-M regression analysis on culm distribution and linear equation calculation showed an average $\alpha$ of 1.0485 and an average $\beta$ of 1.6737 for the two plots, with culms concentrated in average bamboo forest. Observation of distribution tendency for the two plots (Table 4) indicated a mean breast height diameter of $2.58 \mathrm{~cm}$, a median of $2.5 \mathrm{~cm}$ and a standard deviation of 1.03 . DBH ranged from 0.2 to $5.9 \mathrm{~cm}$ (Fig. 5).

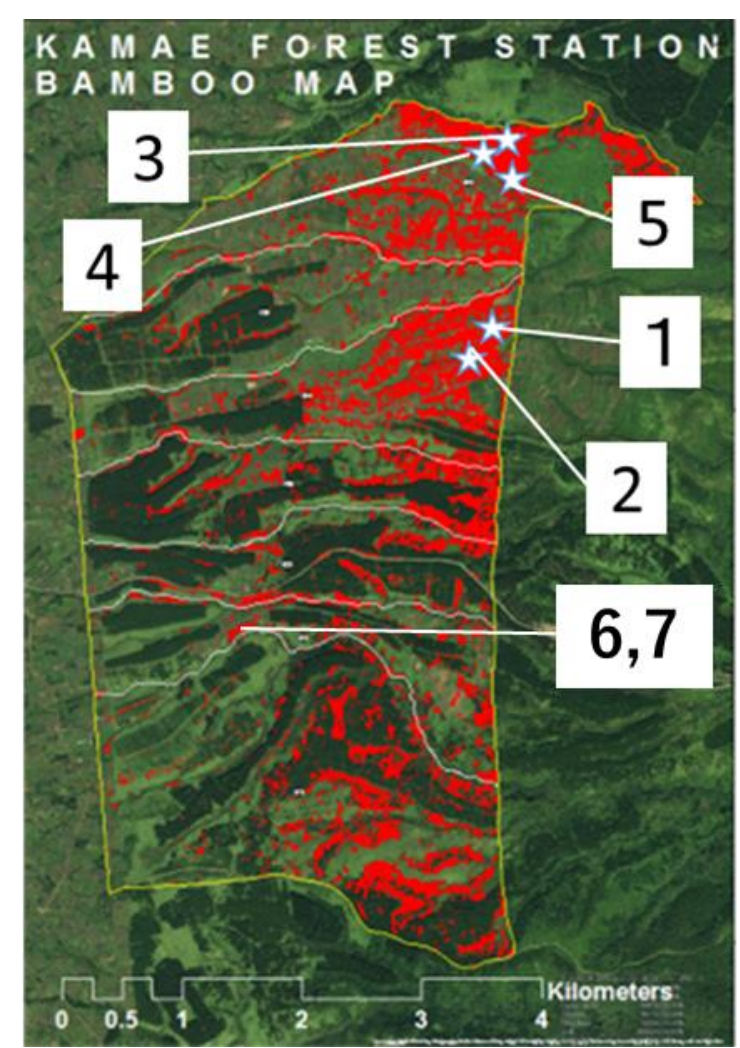

Figure 3. Bamboo area in Kamae Forest Station

Table 1 Density in forest management areas

\begin{tabular}{|l|l|l|}
\hline & $\begin{array}{l}\text { Total culms } \\
10 \times 10(\mathrm{~m})\end{array}$ & Culms/ha \\
\hline Plot 1 & 215 & 21,500 \\
\hline Plot 2 & 214 & 21,400 \\
\hline Plot 3 & 209 & 20,900 \\
\hline Plot 4 & 186 & 18,600 \\
\hline Plot 5 & 175 & 17,500 \\
\hline Average & 199.8 & 19,980 \\
\hline
\end{tabular}


Table 2 Bamboo forest management area $\mathbf{M}-\mathbf{M}^{*}$ regression analysis

\begin{tabular}{|l|c|c|c|l|}
\hline & & $\alpha$ & $\beta$ & \\
\hline Plot 1 & $\mathrm{~m}^{*}=1.1073 \mathrm{~m}+2.3117$ & 1.1073 & 2.3117 & Largest population and strong congestion \\
\hline Plot 2 & $\mathrm{~m}^{*}=1.0861 \mathrm{~m}+3.2089$ & 1.0861 & 3.2089 & $\begin{array}{l}\text { Population larger than average and most likely } \\
\text { to be dense }\end{array}$ \\
\hline Plot 3 & $\mathrm{~m}^{*}=0.9777 \mathrm{~m}+2.672$ & 0.9777 & 2.672 & Smallest group and strong trends \\
\hline Plot 4 & $\mathrm{~m}^{*}=1.0136 \mathrm{~m}+1.5432$ & 1.0136 & 1.5432 & $\begin{array}{l}\text { Population below average with crowding } \\
\text { tendency }\end{array}$ \\
\hline Plot 5 & $\mathrm{~m}^{*}=0.9971 \mathrm{~m}+2.862$ & 0.9971 & 2.862 & $\begin{array}{l}\text { Population below average with crowding } \\
\text { tendency }\end{array}$ \\
\hline Average & $\mathrm{m}^{*}=1.03636 \mathrm{~m}+2.51956$ & 1.03636 & 2.51956 & $\begin{array}{l}\text { Average bamboo grove in a conservation area } \\
\text { with dense tendency }\end{array}$ \\
\hline
\end{tabular}

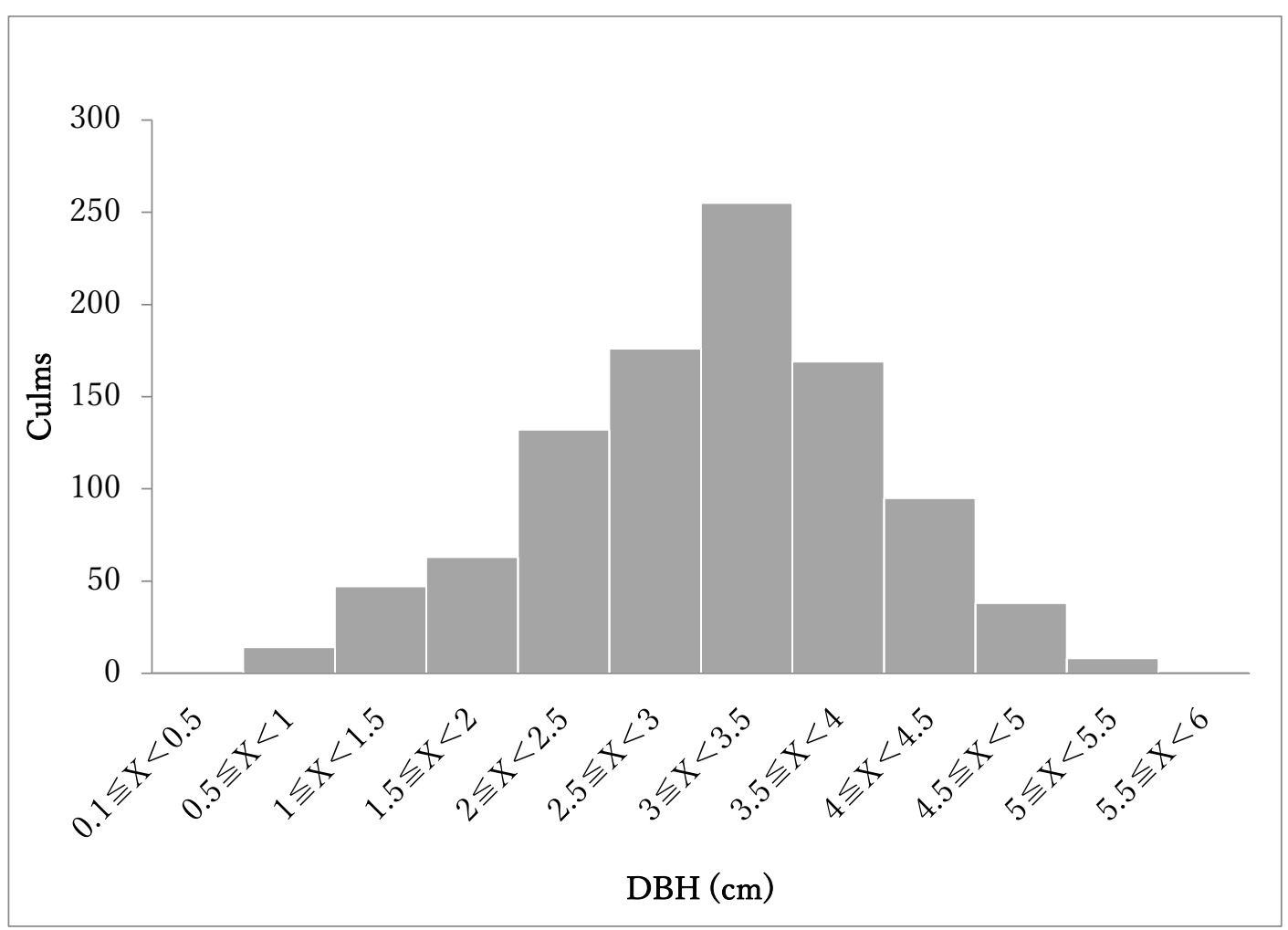

Figure 4. Distribution of bamboo DBH in forest management areas $(\mathrm{N}=999)$

Table 3 Density in common farmland areas

\begin{tabular}{|l|l|l|}
\hline & $\begin{array}{l}\text { Total culms } \\
10 \times 10(\mathrm{~m})\end{array}$ & Culms/ha \\
\hline Plot 6 & 113 & 11,300 \\
\hline Plot 7 & 191 & 19,100 \\
\hline Average & 152 & 15,200 \\
\hline
\end{tabular}


Table 4 Bamboo forest common farmland area $\mathrm{M}-\mathrm{M}^{*}$ regression analysis

\begin{tabular}{|c|c|c|c|c|}
\hline & & $\alpha$ & $\beta$ & \\
\hline Plot 6 & $\mathrm{~m}^{*}=1.0001 \mathrm{~m}+1.682$ & 1.0001 & 1.682 & Density tendency \\
\hline Plot 7 & $m^{*}=1.0969 m+2.1792$ & 1.0969 & 2.1792 & Large group with strong crowding tendency \\
\hline Average & $\mathrm{m}^{*}=1.0485 \mathrm{~m}+1.6737$ & 1.0485 & 1.6737 & Average bamboo grove with dense tendency \\
\hline
\end{tabular}

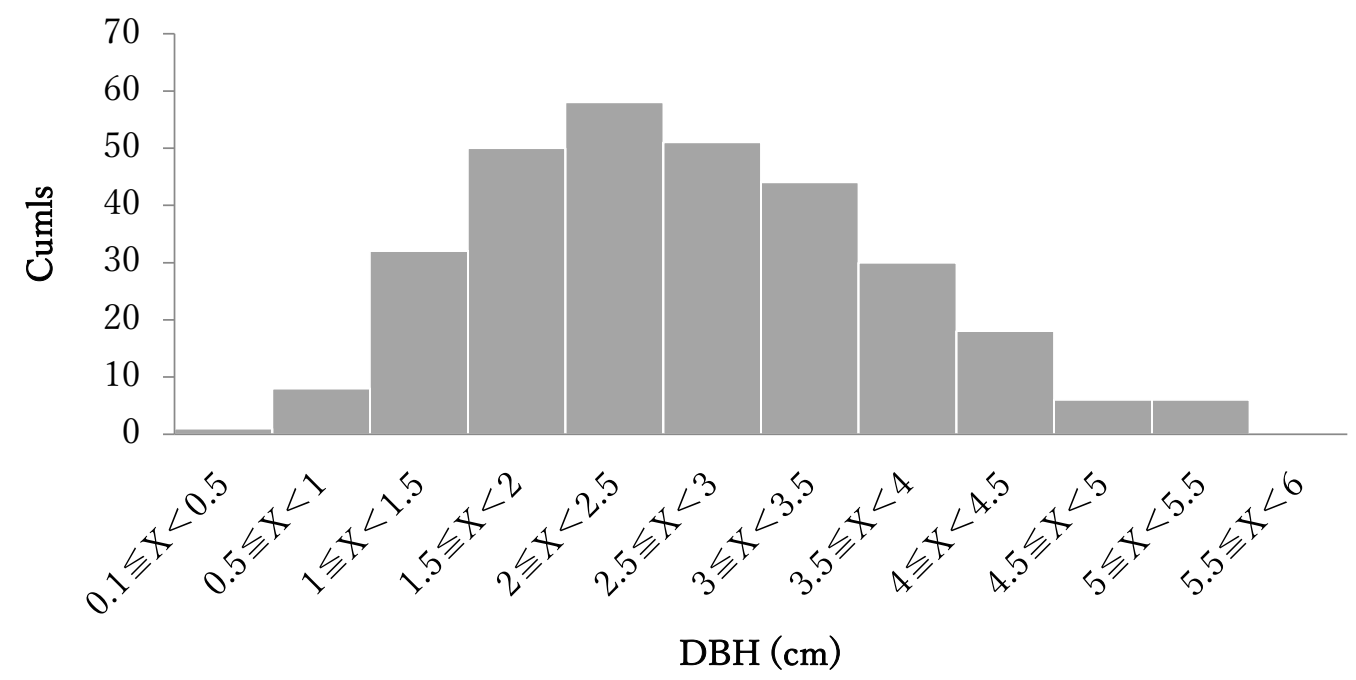

Figure 5. Distribution of bamboo DBH in common farmland areas $(\mathrm{N}=304)$

\section{4-2. Length and DBH}

A total of 50 forest management area bamboo samples were collected, but only 42 were examined due to damaged tops. The average culm length was $690.26 \mathrm{~cm}$, the median was $690 \mathrm{~cm}$, and the standard deviation was 154.81. Culm lengths ranged from 310 to 1,100 cm (Fig. 6).

The relationship between culm length $(\mathrm{L})$ and $\mathrm{DBH}$ was expressed by the linear equation $\mathrm{L}=103.25 \mathrm{DBH}$ $+391.66\left(R^{2}=0.4152\right)$, and a relatively strong positive correlation was observed (Fig. 7). The $t$-value was 3.96 and the p-value was 0.000322 , indicating a significant relationship. These outcomes clarified that $A$. alpina has a longer culm with greater breast-height diameters. 


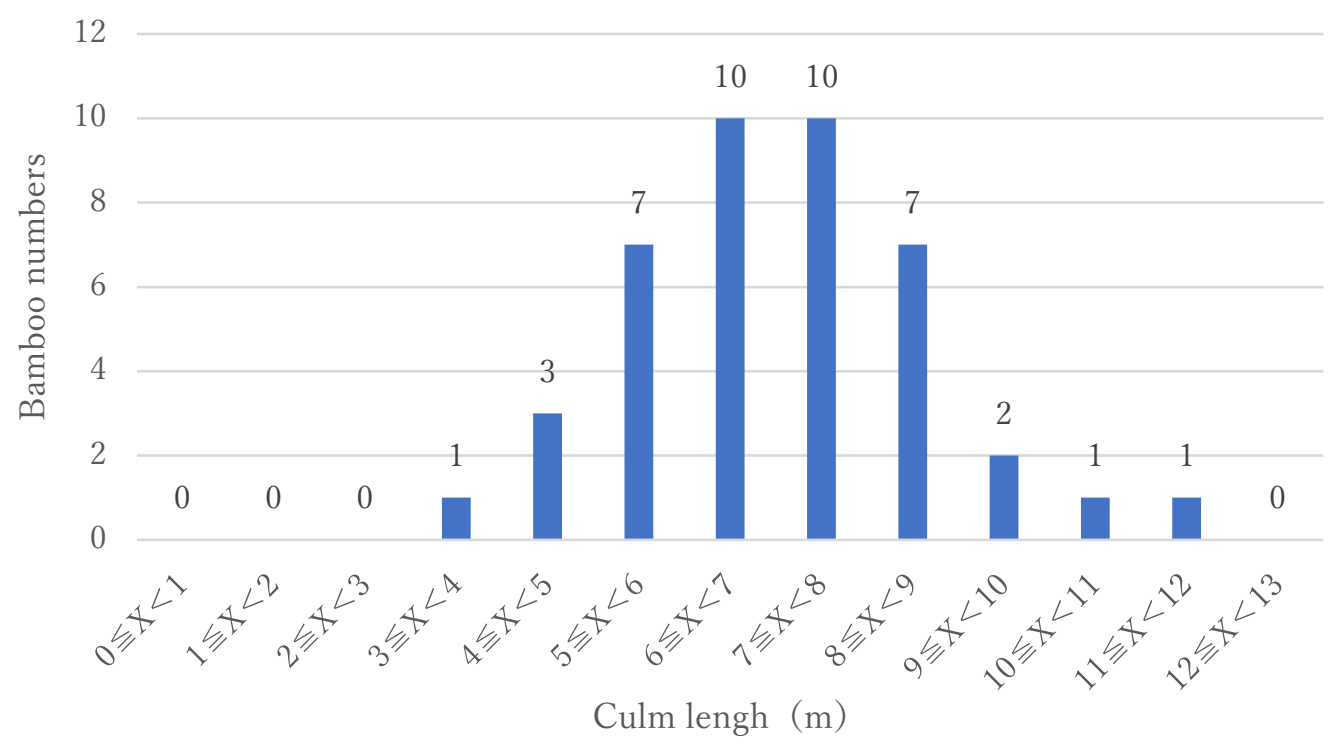

Figure 6. Distribution of length population

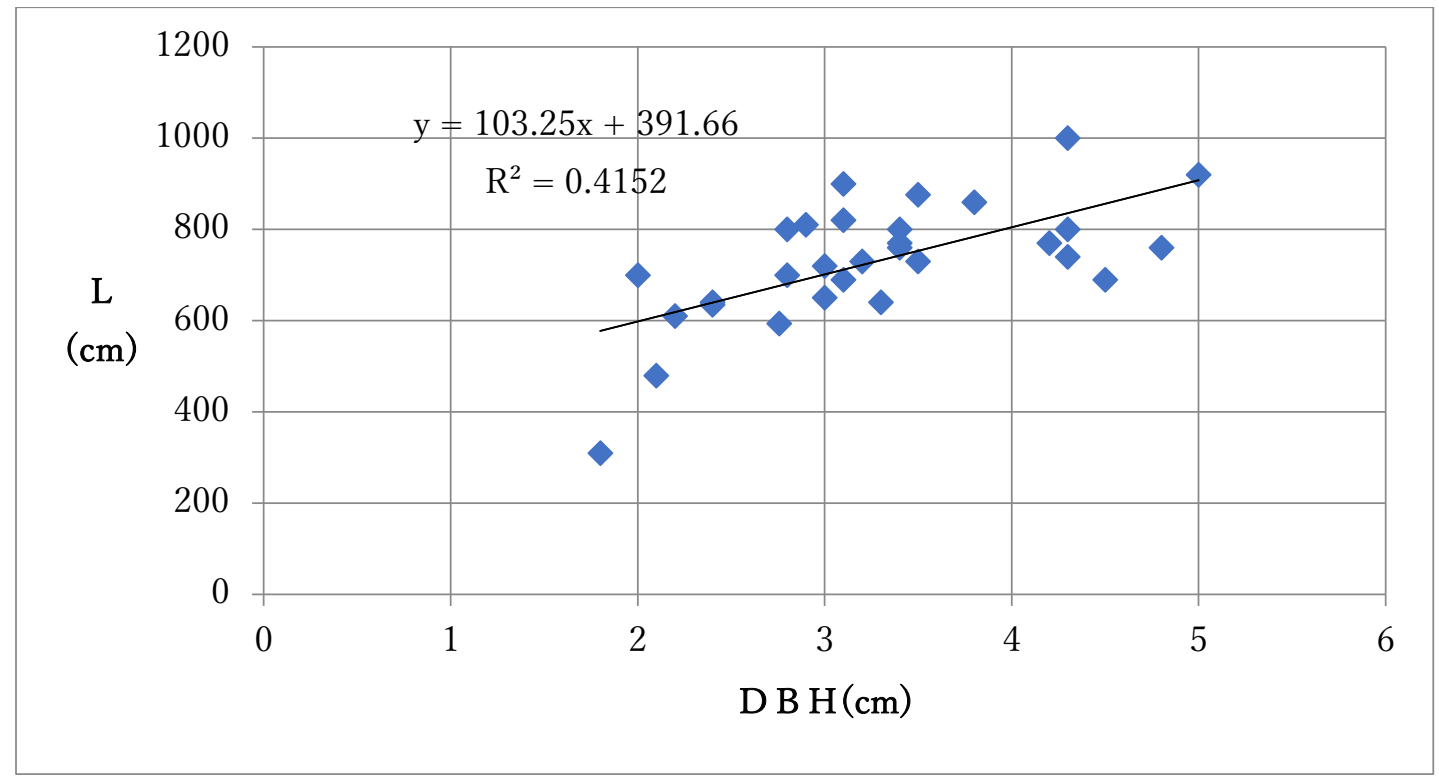

Figure 7. Relation between length and DBH

\section{4-3. AGB estimation}

The average weights of 42 felled bamboo plants by culm length per $1 \mathrm{~m}$ from the ground are shown in Fig. 8. Branches and leaves were heaviest between 6 and $7 \mathrm{~m}$ from the ground, and upper parts were not heavier than lower parts in culms less than $4 \mathrm{~m}$ from the ground. It was therefore presumed that bamboo with culm lengths of $4 \mathrm{~m}$ or more is rich in resources at the top when branches and leaves are taken into consideration. The results of 3-2 indicated an association between larger DBH values and longer culms, suggesting that bamboo with high DBH values can be expected to provide ample resources. Average moisture content at the culm site was the highest at $39.69 \%$ and the lowest in branches at $35.14 \%$, and was $38.44 \%$ in leaves. 
Calculation of correlations between culms, branches, leaves and their total AGB $(\mathrm{Kg})$ and DBH based on the above results (Fig. 9; Table 5) showed a significant relationship for each based on [13], [14] and [15]. The AGB formula (AGB $=0.4503 \mathrm{e} 0.5135 \mathrm{DBH})$ indicated abundant above-ground growth of approximately 18,570.1 $\mathrm{t}$ in bamboo groves (area: $467.37 \mathrm{ha}$ ) in the Kamae forest management area.

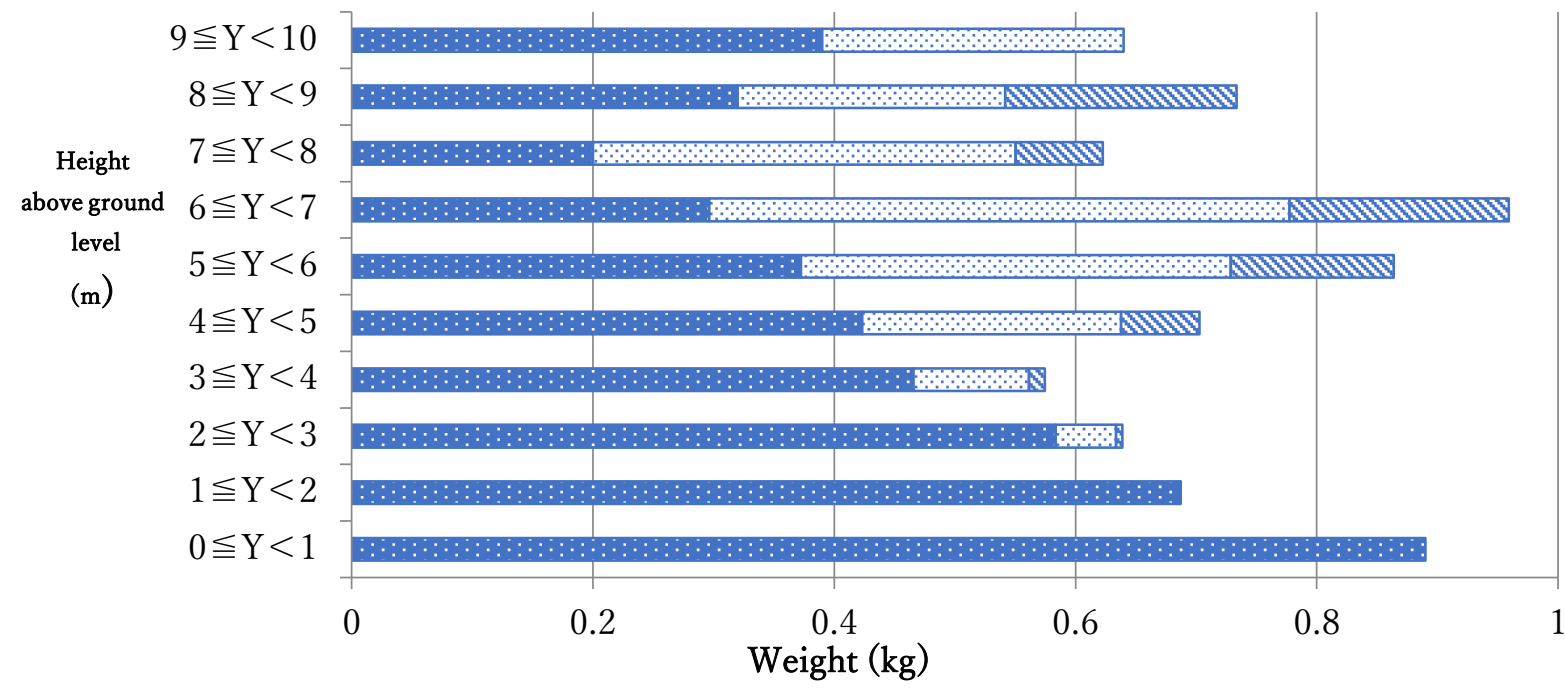

Figure 8. Minimum weights for each height above ground level

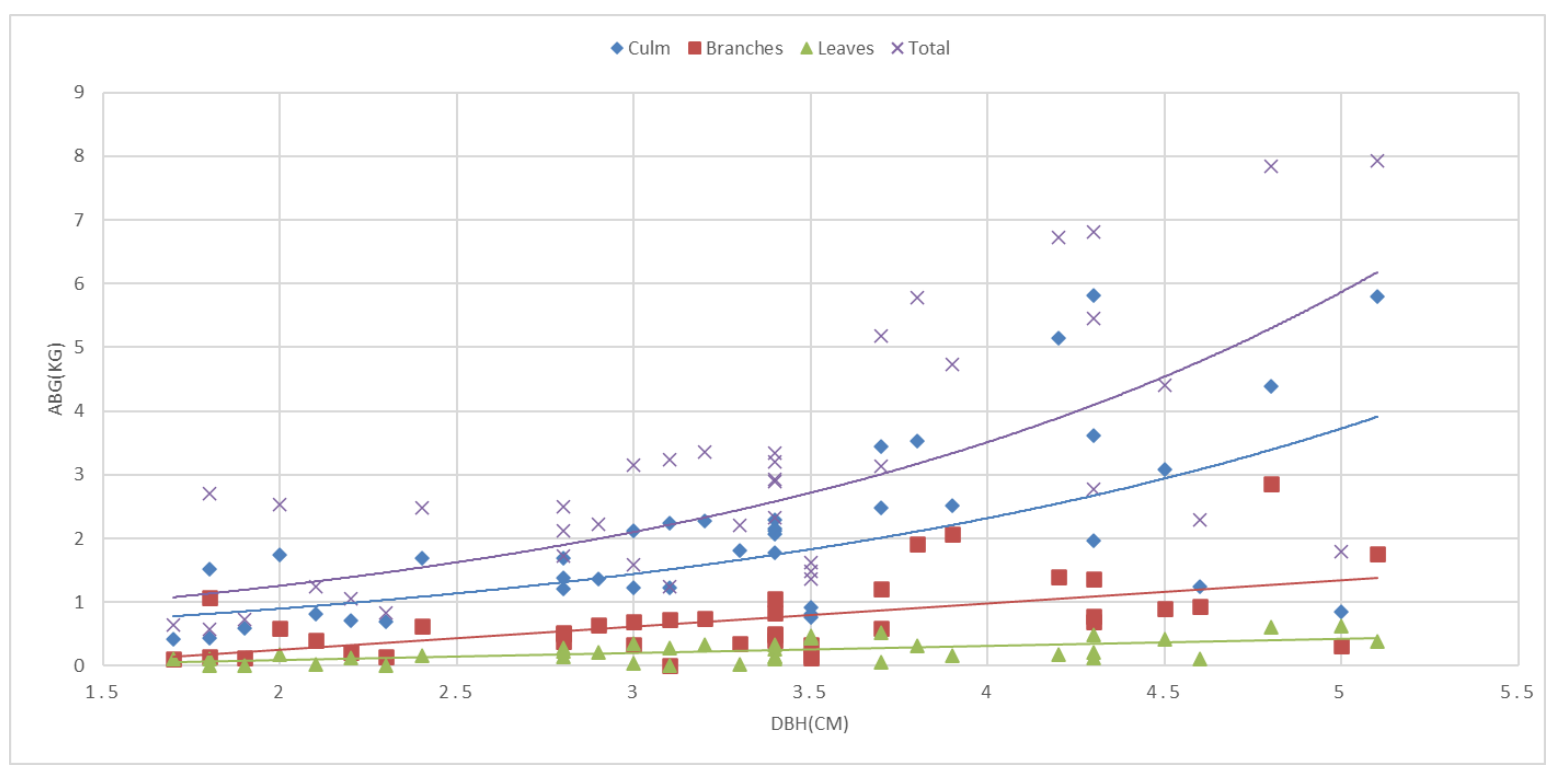

Figure 9. AGB allometric correlation

Table 5 AGB allometric correlation for Arundinaria alpina

\begin{tabular}{|l|l|l|}
\hline AGB & Allometric correlation & $R^{2}$ \\
\hline Total & AGB $=0.4503 \mathrm{e}^{0.5135 \mathrm{DBH}}$ & 0.4946 \\
\hline Culms & $\mathrm{AGB}=0.3475 \mathrm{e}^{0.4745 \mathrm{DBH}}$ & 0.4245 \\
\hline Branches & $\mathrm{AGB}=\mathbf{0 . 3 6 4 9 \mathrm { DBH } - 0 . 4 7 7 6}$ & 0.3048 \\
\hline Leaves & $\mathrm{AGB}=\mathbf{0 . 1 1 2 5 \mathrm { DBH } - 0 . 1 4 0 7}$ & 0.3504 \\
\hline
\end{tabular}

AGB (kg) DBH (cm) 


\section{Discussion}

Forest on common farmland was found to have approximately $20.8 \%$ less bamboo than in forest management areas. Distribution of DBH values per ha of the forest conservation area and common farmland were compared for quantitative evaluation, with results showing fewer values between 2.5 and $5 \mathrm{~cm}$ than bamboo groves in the forest management area (Fig. 10). As the standard deviation was 0.88 for the forest management area and 1.03 for common farmland, there was a variation in DBH values for bamboo on common farmland. Since such farmland is generally residential, it can be inferred that residents may generally use bamboo with values between 2.5 and $5 \mathrm{~cm}$. Standing bamboo in both areas of the forest management area also tended to have a stronger concentrated spatial distribution. The results clarified that culm distribution in native bamboo forest, which is close to a natural state, tends to be constant, and suggest that residents selectively harvest bamboo from grove areas in common agricultural forests rather than clear-logging.

The results of the study clarified that residents around the Kamae Forest management area rely on common farmland for livelihoods with bamboo forest areas retaining $60 \%$ of existing AGB as compared to natural bamboo forests to prevent over-harvesting, and that selective logging was practiced. Forest resources were used by the Kikuyu people (the ancestors of the current inhabitants) even before the White Highlands were cultivated and the Forestry Bureau was established in the first half of the 19th century. The continued existence of bamboo groves in the area is attributed to ongoing sustainable use. Conservation of these traditional groves is considered effective in securing sustainable wood resources.

Efforts to produce wood resources in Kenya include Japan's support of development relating to arid and semi-arid land-resistant tree species since the 1980s [16]. This initiative has evolved into the planting of improved varieties of Melia volkensii in a dry-land-resistance breeding project for adaptation to climate change since 2012 [17]. Initiatives for the utilization of alternative resources to combat insufficient timber resources also include cultivation of the non-native Bambusa vulgaris by the Kenya Forestry Service since 2008 with the support of the International Bamboo Rattan Association [18]. Kenya has a long history of greening to promote wood resources, and the South American Prosopis juliflora was planted on a large scale in western Kenya in the 1960s to provide fuel wood and promote early greening. However, in the 1990s the species was found to damage the native natural environment [19], and a project to eliminate it was started in 2010 [20].

Promotion of forest growth projects in developing countries by developed and other countries is an internationally significant activity contributing to SDG achievement. The uniform selection of species such as $P$. juliflora under national afforestation policies has supported successful greening, but negatively affects native vegetation in the long run. Ecological reports are issued annually regarding the planting of the improved cultivar M. volkensii. However, cash-strapped farmers need funds to obtain breeding species and to enable annual purchases for ongoing planting of F1 seeds.

As a result, artificial forests are generally cultivated as new plantations in developing countries, and economic forests are typically managed for commercial timber production.

However, this study focused on natural living forests (natural or related secondary types) used for local acquisition of wood, with operations for the coexistence and supply of various resources in line with local need [21]. Accordingly, future work must include examination of sustainable forest development and wood resource management in consideration of target forest types and local residents, selection of suitable plants based on traditional expertise and localities, and conversion of empirical information into data for verification. 


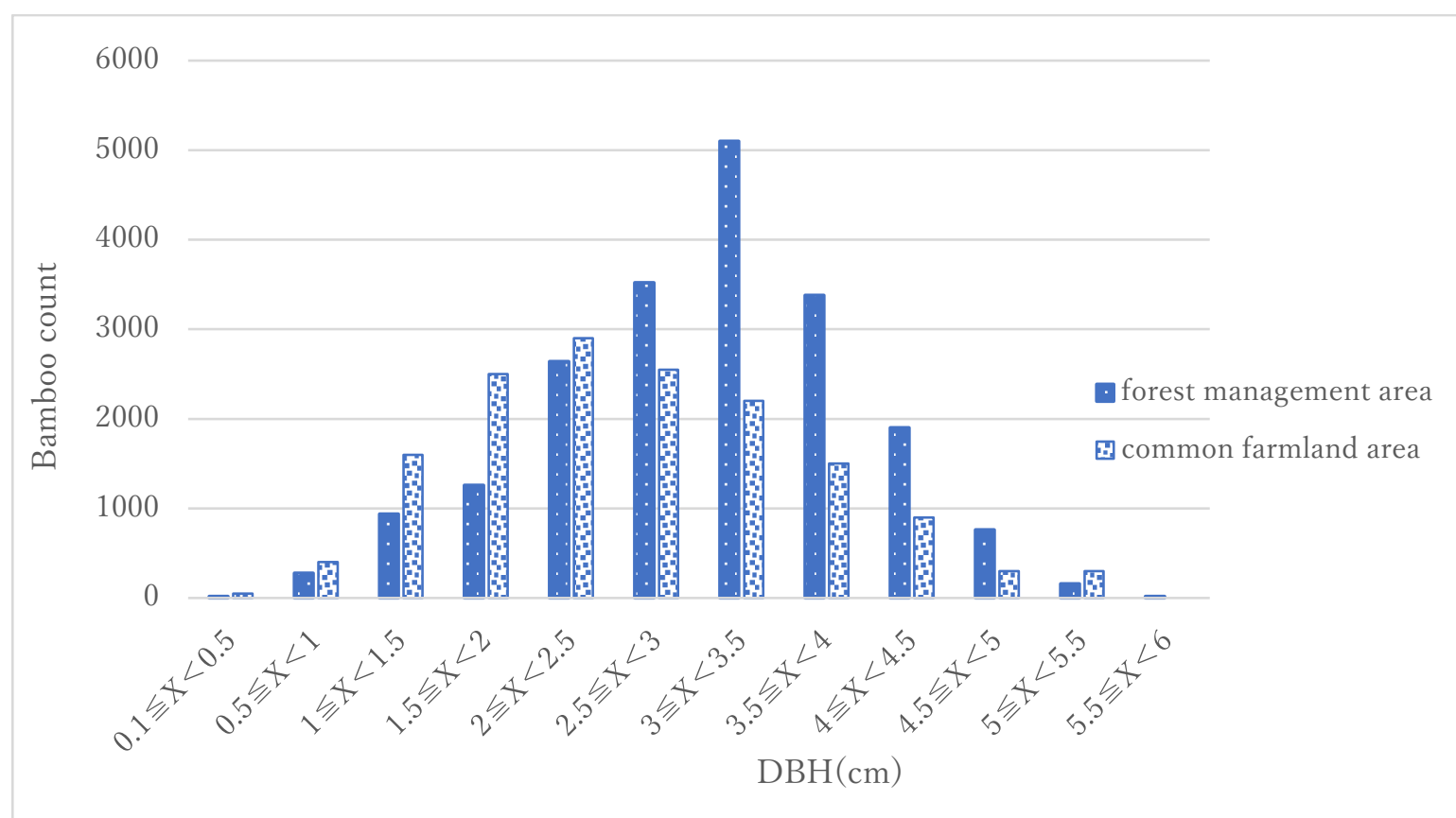

Figure 10. Bamboo distribution in forest management and common farmland areas

\section{Conclusions}

The study's results indicated that Kamae locals use bamboo forests sustainably in their livelihoods. Planting is conducted to ensure wood resources and prevent forest loss to enable the production of fuel wood and charcoal. However, consideration for indigenous vegetation and local traditional usage tends to be lacking in these activities. Against such a background, the use of indigenous species and traditional management in future activities can be expected to support ongoing sustainable and economic forest management.

\section{Funding: This work was supported by a JSPS Research Fellow Grant-in-Aid (no. 18J20100; https://www.jsps.go.jp/english/index.html).}

Acknowledgments: Thanks are due to Professor John Njoroge (Jomo Kenyatta University of Agriculture and Technology) for the research advice and personal support provided during the study. The input of the Kenyan Forestry Service, Kamae residents and students at Jomo Kenyatta University of Agriculture and Technology is also very much appreciated.

Conflicts of interest: The authors have no conflicts of interest to declare.

\section{References}

1. Kenya Forest Service, 2011. Report on National Forest Resource Mapping and Capacity Development for The Republic of Kenya.

2. JAFTA, 2000. Forests and forestry in developing countries.

3. Kigomo, B. N., Studies on the regeneration and growth characteristics of Brachylaena huillensis in semi-deciduous forests of Kenya, University of Oxford.

4. Watanabe, M., 1972. Report on technical service and research work on silviculture and management of bamboo forest in Thailand. 
5. Marshall, F., 2001. Agriculture and use of wild and weedy greens by the Piik AP Oom Okiek of Kenya. Economic Botany, 55 (1), pp. 32-46.

6. W. D. Clayton, 1970. Flora of Tropical East Africa, Part (Part 1), p. 1.

7. KENYATTA, J., 1979. No title. Facing Mount Kenya : the traditional life of the Gikuyu, .

8. Motoji Matsuda, Miwa Tsuda ,2012.55chanters to know about Kenya. Kyoto University.

9. Makoto Goto,2008. Structural analysis of abandoned bamboo grove based on the abandoned bamboo forest based on the abundance of the above-ground part and the stand composition obtained from the allometry formula. JASS, 24(4), pp. 223-232

10. Miyuki Kaku, 2014 Possibility of sustainable use of bamboo culm fuel and bamboo grove management based on estimation of bamboo culm amount in Awaji Island, Hyogo Prefecture. Environmental information science, 28(0), pp. 19-24.

11. Sohel, M. S. I., Alamgir, M., Akhter, S. and Rahman, M., 2015. Carbon storage in a bamboo (Bambusa vulgaris) plantation in degraded tropical forests: Implications for policy development. Land Use Policy, 49, pp. 142-151.

12. Masato Tamura, 1998. Introduction to Community Ecology. House Pests, 20(2), pp. 94-100.

13. Suganuma, H., Kawada, K. et al, A.S., 2012. Allometric Equations and Biomass Amount of Representative Tunisian Arid Land Shrubs for Estimating Baseline. Journal of Arid Land Studies : 22 (1), pp. 219-222.

14. Buckingham, K. C., Wu, L. and Lou, Y., 2013. Can't See the (Bamboo) Forest for the Trees: Examining Bamboo's Fit Within International Forestry Institutions. Ambio, 43 (6), pp. 770-778.

15. Jyoti Nath, A., Das, G. and Das, A. K., 2009. Above ground standing biomass and carbon storage in village bamboos in North East India. Biomass \& Bioenergy, 33 (9), pp. 1188-1196.

16. Yuichi Sato, 2007. Technical reports,. Forestry Agency, Ministry of Agriculture, Forestry and Fisheries

17. So Hanaoka, 2011. Breeding and research situation of Melia volkensii in the Republic of Kenya. Forest tree breeding, (239), pp. 27-29.

18. Inbar, 2014. Bamboo for Africa: A strategic resource to drive the continent's Green Economy.

19. Peter Wass, 1995. Kenya's Indigenous Forest Status, Management and Conservation, IUCN.

20. Muturi, G. M., Kariuki, J. G., Machua, J. M., Kamondo, B., Tuwei, P., Wanjiku, J. and Ochieng, D., 2014. Rehabilitation of Degraded Areas Surrounding Kakuma Refugee Camp. KEFRI/JOFCA Technical report (unpublished).

21. Taturo Fujimori, 2001. Ecological and silvicultural strategies for sustainable forest management. Amsterdam; Tokyo: Elsevier. 